\title{
Determinan Struktur Modal dalam Perspektif Pecking Order Theory dan Agency Theory
}

\author{
Nana Umdiana ${ }^{1 *}$, Shifa Tivanna ${ }^{2}$ \\ 1, 2 Universitas Serang Raya \\ 1Nanaumdianaunsera@gmail.ac.id \\ ${ }^{*}$ Penulis korespondensi
}

\begin{abstract}
The capital structure seen from the perspective of pecking order theory explains that companies are more likely to prefer internal funding than external companies. Pecking Order Theory explains why highly profitable companies generally have less debt. This study aims to discuss Liquidity, Asset Structure, Business Risk, Growth Opportunity, Managerial Ownership of Capital Structures on Manufacturing Companies of the basic Consumer Good Industry Sector listed on the Indonesia Stock Exchange period 2016- 2019. This type of research is an associative causal research with the type of time series. The sample was selected using the purposive sampling method. Data analyzed amounted to 40. Data was tested using multiple linear regression analysis. The result of this study indicate that Liquidity is significant affect the Capital Structure. Asset Structure, Business Risk, Growth Opportunity, Managerial Ownership did not affect the Capital Structures.
\end{abstract}

Keywords: Capital Structures, Pecking Order Theory, Agency Theory

\begin{abstract}
Abstrak
Struktur modal dilihat dari perspektif pecking order theory menjelaskan bahwa perusahaan lebih cenderung memilih pendanaan yang berasal dari internal dari pada eksternal perusahaan. Pecking Order Theory menjelaskan mengapa pada perusahaan yang sangat menguntungkan pada umumnya mempunyai utang yang lebih sedikit. Penelitian ini bertujuan untuk mengetahui pengaruh Likuiditas, Struktur Aktiva, Risiko Bisnis, Growth Oppotunity, Kepemilikan Manajerial terhadap Struktur Modal Pada Perusahaan Manufaktur Sektor Industri Barang Konsumsi yang Terdaftar di Bursa Efek Indonesia Pada Periode 2016-2019. Jenis penelitian ini adalah penelitian asosiatif kausal dengan jenis data menggunakan deret waktu (time series). Sampel diambil dengan menggunakan teknik purposive sampling. Data penelitian yang dianalisis berjumlah 40. Data diuji menggunakan teknik analisis regresi berganda. Hasil penelitian ini menunjukan bahwa Likuiditas berpengaruh terhadap Struktur Modal. Struktur Aktiva, Risiko Bisnis, Growth Oppotunity, Kepemilikan Manajerial tidak berpengaruh terhadap Struktur Modal.
\end{abstract}

Kata Kunci: Struktur Modal, Pecking Order Theory, Agency Theory 


\section{PENDAHULUAN}

Struktur modal merupakan topik yang kompleks dan salah satu faktor yang menentukan nilai perusahaan, Struktur modal merupakan masalah yang penting bagi perusahaan karena baik buruknya struktur modal akan mempunyai efek langsung terhadap posisi keuangan perusahaan. Efek langsung yang disebabkan oleh struktur modal dapat mempengaruhi nilai suatu perusahaan. Struktur modal merupakan keputusan keuangan yang berkaitan dengan pendanaan. Struktur modal juga merupakan perimbangan atau perbandingan antara modal asing dan modal sendiri. Modal asing diartikan dalam hal ini adalah utang baik jangka panjang maupun jangka pendek. Sedangkan modal sendiri bisa terbagi atas laba ditahan dan bisa juga dengan penyertaan kepemilikan perusahaan.

Struktur modal yang efektif mampu menciptakan perusahaan dengan keuangan yang kuat dan stabil. Dalam melihat struktur modal perusahaan, investor tidak dapat dipisahkan dari informasi perusahaan berupa laporan keuangan yang dikeluarkan setiap tahunnya. Para investor akan melakukan berbagai analisis terkait dengan keputusan untuk menanamkan modalnya pada perusahaan melalui informasi yang salah satunya berasal dari laporan keuangan perusahaan. Sektor Barang Konsumsi, merupakan salah satu sektor usaha yang terus mengalami pertumbuhan dan perkembangan yang sangat pesat, akan tetapi perkembangan yang pesat bukan berarti tidak mempunyai masalah. Masalah yang ada di perusahaan tersebut adalah tidak mampu melakukan kombinasi utang dengan modal yang baik, sehingga menimbulkan dampak risiko bisnis yang cukup tinggi. Masalah pendanaan merupakan bagian terpenting yang berkaitan yang berkaitan dengan kegiatan operasional perusahaan dan melibatkan banyak pihak seperti kreditor, pemegang saham, serta manajemen perusahaan itu sendiri. Pendanaan tersebut dapat berasal dari internal perusahaan yang berasal dari modal saham, laba ditahan dan sedangkan eksternal perusahaan berupa dana yang berasal dari utang (Agus, 2012). Manajer keuangan dituntut mampu untuk menciptakan struktur modal yang optimal dengan cara menghimpun dana dari dalam maupun luar perusahaan secara efisien. Keputusan pendanaan atau struktur modal yang tidak cermat akan berpengaruh langsung terhadap penurunan laba yang dihasilkan perusahaan tersebut.

PT. Tri Banya Tirta Tbk adalah Salah satu perusahaan di sektor makanan dan minuman setiap tahunnya mengalami kerugian dari tahun 2016-2018, dilihat dari laporan keuangan tersebut sumber pendanaan eksternal (utang) lebih besar dari sumber pendaanaan internal (modal sendiri) yang mengakibatkan perusahaan tersebut tidak bisa menutupi utangnya yang akan mengakibatkan kondisi perusahaan tidak baik. Ditahun 2016 utang sebesar Rp.684.252.214.422 modal Rp.480.841.418.401, tahun 2017 utang Rp.690.099.182.411 modal Rp.419.284.788.700 dan tahun 2018 Rp.722.716.844.799 modal Rp.387.126.677.545, dari data tersebut PT. Tri Banya Tirta Tbk yang mengakibatkan kinerja keuangan tidak baik dan struktur modal yang tidak optimal, perusahaan kesulitan menarik investor untuk menanamkan sahamnya, karena investor akan melihat laporan keuangan. Jika kondisi keuangannya tidak sehat perusahaan perlu mengevaluasi dan mengoptimalkan agar perusahaan bisa bertahan dan bersaing dengan perusahaan lain. Masalah struktur modal merupakan masalah yang penting bagi setiap perusahaan, karena 
tinggi rendahnya struktur modal suatu perusahaan akan mencerminkan bagaimana posisi finansial perusahaan tersebut. Manajer keuangan dituntut mampu untuk menciptakan struktur modal yang optimal dengan cara menghimpun dana dari dalam maupun luar perusahaan secara efisien. Keputusan pendanaan atau struktur modal yang tidak cermat akan berpengaruh langsung terhadap penurunan laba yang dihasilan perusahaan tersebut. Jika utang semakin besar akan menyebabkan semakin besar risiko yang harus dihadapi perusahaan, antara kesulitan keuangan, kesulitan membayar bunga dan pokok pinjaman sampai kebangkrutan.

Struktur modal dalam penelitian ini memiliki dua teori yaitu pecking order theory dan agency theory. Penelitian ini menganalisis variabel Likuiditas Struktur Aktiva, Risiko bisnis, Growth Opportunity, dalam perspektif pecking order theory dan Kepemilikan Manajerial dalam perspektif Agency Theory. Struktur modal dilihat dari perspektif pecking order theory menjelaskan bahwa perusahaan lebih cenderung memilih pendanaan yang berasal dari internal dari pada eksternal perusahaan. Utang menjadi pilihan kedua setelah sumber pendanaan internal, Pecking Order Theory menjelaskan mengapa pada perusahaan yang sangat menguntungkan pada umumnya mempunyai utang yang lebih sedikit. Hal ini terjadi bukan karena perusahaan tersebut mempunyai target debt ratio yang rendah, tetapi disebabkan karena perusahaan memang tidak membutuhkan dana dari pihak ekstenal (Lestari 2015). Jika pendanaan eksternal diperlukan, perusahaan akan mengeluarkan surat berharga yang paling aman terlebih dahulu. Perusahaan akan memulai dengan utang, kemudian dengan surat berharga dan saham sebagai pilihan terakhir. Untuk Agency Theory menurut pendekatan ini konfik anatara pemegang saham dengan manajer adalah konsep free cash flow, ada kecendrungan manajer ingin menahan sumber daya sehingga mempunyai kontrol atas sumber daya tersebut. Utang sebagai cara untuk mengurangi konflik keagendaan free cash flow. Jika perusahaan menggunakan utang, maka manajer akan dipaksa untuk mengeluarkan kas dari perusahaan untuk membayar bunga. Kegunaan Agency Theory ini Manajer diberikan insentif yang memadai agar dapat melakukan fungsinya dengan baik. Di samping itu juga perlu dilakukan pengawasan terhadap manajer dengan cara seperti pengikatan agen, pemeriksaan laporan keuangan, dan pembatasan terhadap keputusan yang dapat diambil manajemen.

\section{Pengaruh Likuiditas terhadap Struktur Modal}

Likuiditas merupakan kemampuan perusahaan dalam memenuhi kewajiban jangka pendeknya. Kemampuan tersebut adalah kemampuan perusahaan dalam melanjutkan kegiatan operasionalnya pada saat perusahaan diwajibkan untuk melunasi kewajibannya yang akan mengurangi dana operasionalnya. Perusahaan mampu memenuhi kewajiban keuangannya tepat waktu artinya perusahaan tersebut dalam keadaan liquid dan dapat dikatakan mampu memenuhi kewajiban keuangan tepat waktu jika perusahaan tersebut memiliki alat pembayaran ataupun aktiva lancar yang lebih besar daripada utang lancar atau utang jangka pendek dan sebaliknya (Munawir, 2014). Kemampuan likuiditas perusahaan dapat mengurangi tingkat utang atas kemampuan perusahaan. Hasil penelitian 
sama halnya dengan Devi, Sulindawati, and Wahyuni (2017). Berdasarkan argumentasi tersebut maka hipotesis dirumuskan sebagai berikut.

$\mathbf{H}_{\mathbf{1}}$ : Likuiditas berpengaruh terhadap Struktur Modal

\section{Pengaruh Struktur Aktiva terhadap Struktur Modal}

Struktur aktiva merupakan perbandingan antara aktiva tetap dengan total aktiva yang dimiliki perusahaan yang dapat menentukan besarnya alokasi dana untuk masing-masing komponen aktiva. Semakin tinggi struktur aktiva perusahaan menunjukkan semakin tinggi kemampuan perusahaan mendapatkan jaminan utang jangka panjang. Perusahaan dengan struktur aktiva tinggi cenderung memilih menggunakan dana dari pihak eksternal untuk mendanai kebutuhan modalnya. perusahaan yang berukuran besar memiliki struktur aktiva yang tinggi dan memiliki kemampuan dan fleksibilitas yang lebih untuk mengakses sumber dana eksternal sehingga cenderung meningkatkan utang.

Hal itu terjadi karena kreditur lebih tertarik pada perusahaan besar dibandingkan perusahaan kecil sebab pinjaman dari kreditor membutuhkan jaminan yang setimpal dengan jumlah yang dipinjamkan pada perusahaan. Perusahaan kecil tidak mudah untuk mendapatkan modal asing berupa utang jangka panjang sehingga cenderung menggunakan utang jangka pendek dan modal sendiri. Hasil penelitian sama halnya dengan Santoso dan Priantinah (2016). Berdasarkan argumentasi tersebut maka hipotesis dirumuskan sebagai berikut:

$\mathbf{H}_{2}$ : Struktur Aktiva berpengaruh terhadap Struktur Modal

\section{Pengaruh Risiko Bisnis terhadap Struktur Modal}

Risiko Bisnis merupakan salah satu indikator penting bagi perusahaan dalam menentukan sistem pendanaan perusahaan terutama dalam keputusan penggunaan utang. Menurut pecking order theory, perusahaan lebih menyukai penggunaan pendanaan dari modal internal, yaitu dana yang berasal dari aliran kas, laba ditahan, dan akumulasi depresiasi. Sebelum memutuskan penggunaan utang, manajemen perlu mempertimbangkan terlebih dahulu risiko bisnisnya.

Risiko bisnis merupakan risiko dari perusahaan saat tidak mampu menutupi biaya operasionalnya dan dipengaruhi oleh stabilitas pendapatan dan biaya. Perusahaan dan risiko bisnis yang tinggi cenderung menghindari pendanaan dengan menggunakan utang dibandingkan dengan perusahaan yang memiliki risiko bisnis lebih rendah. Risiko perusahaan yang tinggi pada umumnya lebih mengutamakan penggunaan dana internal daripada penggunaan utang maupun penerbitan saham. Hasil penelitian sama halnya dengan Santoso and Priantinah (2016) dan Lestari (2015). Berdasarkan argumentasi tersebut maka hipotesis dirumuskan sebagai berikut:

$\mathbf{H}_{3}$ : Risiko Bisnis berpengaruh terhadap Struktur Modal

\section{Pengaruh Growth Opportunity terhadap Struktur Modal}

Growth opportunity disebut juga kesempatan suatu perusahaan untuk tumbuh di masa yang akan datang (Brigham dan Houston, 2001) dalam (Tuti Meutia 2016). 
Pertumbuhan perusahaan sangat diharapkan oleh pihak internal maupun eksternal perusahaan, karena pertumbuhan yang baik memberi tanda bagi perkembangan perusahaan. Perusahaan dengan prospek pertumbuhan tinggi biasanya lebih banyak dana internal untuk mendanai operasional perusahaannya, Perusahaan dengan prospek pertumbuhan tinggi lebih banyak mengandalkan modal internal perusahaan. tingkat pertumbuhan perusahaan yang tinggi akan lebih banyak menggunakan dana internal dalam struktur modalnya, daripada perusahaan yang tingkat pertumbuhan perusahaannya rendah. Semakin besar asset, diharapkan semakin besar hasil operasional yang dihasilkan oleh perusahaan.

Perusahaan dengan prospek pertumbuhan kecil menggunakan lebih banyak utang karena perusahaan tersebut akan membutuhkan dana yang besar untuk tumbuh dan mengembangkan usahanya yang tidak dapat dipenuhi semuanya melalui modal sendiri (Brigham dan Houston, 2006). Hasil penelitian sama halnya dengan dan Tuti Meutia (2016) dan (Lestari 2015). Berdasarkan argumentasi tersebut maka hipotesis dirumuskan sebagai berikut

$\mathbf{H}_{4}$ : Growth Opportunity berpengaruh terhadap Struktur Modal

\section{Pengaruh Kepemilikan Manajerial terhadap Struktur Modal}

Kepemilikan manajerial adalah kepemilikan saham oleh manajemen perusahaan yang diukur dengan persentase jumlah saham yang dimiliki oleh manajemen (Sujono dan Soebiantoro, 2007). Apabila manajer memiliki saham perusahaan (kepemilikan manajerial) maka akan berpengaruh terhadap keputusan pendanaan perusahaan. Para manajer akan berusaha mengeluarkan kebijakan yang akan mendorong perusahaan untuk mencapai laba yang tinggi dan mengembangkan perusahaan tersebut. Pengembangan perusahaan membutuhkan modal baru. Penggunaan kewajiban atau mengeluarkan saham akan dipilih oleh para manajer. Oleh karena itu kepemilikan manajerial berpengaruh terhadap struktur modal.

Bukti empiris dari Santoso and Priantinah (2016) menunjukkan bahwa kepemilikan manajerial berpengaruh terhadap struktur modal dimana semakin tinggi kepemilikan manajerial maka semakin rendah penggunaan utang perusahaan. Menurut Santoso dan Priantinah (2016) pada hasil penelitiannya mengindikasikan bahwa pendanaan yang bersumber dari kewajiban menjadi tidak menarik bagi para manajer karena akan membebankan risiko yang lebih tinggi bagi dirinya. Hal ini selaras dengan penelitian yang dilakukan oleh Santoso and Priantinah (2016) bahwa perusahaan yang sebagian sahamnya dimiliki oleh manajer cenderung menerapkan kebijakan utang yang kecil karena manajemen ikut menanggung biaya modal yang ditanggung oleh perusahaan. Hasil penelitian tersebut sama halnya dengan Yuswanandre Santoso (2016). Sedangkan terdapat perbedaan hasil kepemilikan manajerial tidak berpengaruh terhadap struktur modal (Lestari, 2015 dan Devi et al., 2017). Berdasarkan argumentasi tersebut maka hipotesis dirumuskan sebagai berikut:

$\mathbf{H}_{5}$ : Kepemilikan Manajerial berpengaruh terhadap Struktur Modal 


\section{METODE}

Populasi dalam penelitian ini adalah perusahaan manufaktur Sektor Industri Barang Konsumsi yang terdaftar di Bursa Efek Indonesia (BEI) dengan periode 2016-2019 terdapat 51 perusahaan. Teknik pemilihan sampel menggunakan purposive sampling. Berdasarkan kriteria seleksi sampel dengan metode purposive sampling dapat diperoleh sebanyak 10 perusahaan dengan rician sebagai berikut:

Tabel 1 Kriteria Pemilihan Sampel

\begin{tabular}{|c|c|}
\hline Uraian & Jumlah \\
\hline Sektor Industri Barang Konsumsi yang terdaftar di BEI pada tahun 2016-2019 & 51 \\
\hline \multicolumn{2}{|l|}{ Yang tidak memenuhi kriteria sempel: } \\
\hline 1. Perusahaan yang menghasilkan kerugian & $(18)$ \\
\hline $\begin{array}{l}\text { 2. Perusahan yang tidak menerbitkan data mengenai kepemilian Manajerial (jumlah saham } \\
\text { yang dimiliki oleh dewan direksi dan komisaris) }\end{array}$ & $(23)$ \\
\hline Jumlah perusahaan yang akan digunakan sebagai sampel & 10 \\
\hline
\end{tabular}

Sumber: hasil olahan data

\section{Definisi Operasional}

\section{Struktur Modal}

Modal adalah hak atau bagian yang dimiliki oleh perusahaan (Kasmir 2010). Komponen modal terdiri dari sektor, agio saham, laba ditahan, cadangan laba dan lainnya. Menurut Munawir (2001), modal merupakan hak atau bagian yang dimiliki oleh perusahaan yang terdapat pada sisi kanan neraca perusahaan yaitu pada post modal saham atau laba ditahan sedangkan modal terdiri dari modal asing dan modal sendiri. Pertimbangan antara seluruh modal asing dan modal sendiri disebut struktur keuangan sedangkan pertimbangan antara modal asing dan modal sendiri yang bersifat jangka panjang akan membentuk struktur permodalan. Menurut Lestari (2015), struktur modal diukur menggunakan rumus sebagai berikut:

$$
D E R=\frac{\text { Total Utang }}{\text { Total Modal }}
$$

\section{Likuiditas}

Likuiditas menunjukkan kemampuan suatu perusahaan untuk memenuhi kewajiban keuangannya yang harus segera dipenuhi, atau kemampuan perusahaan untuk memenuhi kewajiban keuangan pada saat ditagih (Munawir, 2007). Menurut Mardiyanto (2009), likuiditas dapat diukur menggunakan rumus sebagai berikut:

$$
C R=\frac{\text { Aset Lancar }}{\text { Utang Lancar }}
$$




\section{Struktur Aset}

Lukman Syamsudin (2007) menyatakan struktur aktiva adalah penentuan berapa besar alokasi dana untuk masing-masing komponen aktiva, baik dalam aktiva lancar maupun aktiva tetap. Struktur aktiva dapat diukur menggunakan rumus (Devi et al., 2017):

$$
F A R=\frac{\text { Total Aktiva Tetap }}{\text { Total Aktiva }}
$$

\section{Risiko Bisnis}

Menurut Gitosudarmo (2002), risiko adalah suatu keadaan di mana kemungkinan timbulnya kerugian atau bahaya itu dapat diperkirakan sebelumnya dengan menggunakan data atau informasi yang cukup terpercaya atau relevan yang tersedia. Menurut Weston Capeland (2008), risiko bisnis dapat dihitung dengan Bussuness Risk (BRISK) dengan rumus sebagai berikut:

$$
\text { BRISK }=\frac{E B I T}{\text { Total Asset }}
$$

\section{Growth Opportunity}

Peluang pertumbuhan (growth opportunity) adalah tingkat pertumbuhan perusahaan di waktu yang akan datang. Menurut Kartini dan Arianto (2008) dalam Sigita Lestari (2015), definisi lain dari peluang pertumbuhan adalah perubahan total aktiva yang dimiliki perusahaan. Menurut Prayogo (2016), growth opportunity dapat diukur menggunakan rumus sebagai berikut:

$$
\text { Growth Opportunity }=\frac{\text { Total Aset }_{t}-\text { Total Aset }_{t-1}}{\text { Total Aset }_{t-1}}
$$

\section{Kepemilikan Manajerial}

Kepemilikan manajerial adalah proporsi pemegang saham dari pihak manajemen yang secara aktif ikut dalam pengambilan keputusan perusahaan (direktur dan komisaris) (Yayan Suditanto, 2016). Kepemilikan manajerial dapat diukur menggunakan rumus sebagai berikut (Lestari 2015):

$$
K M=\frac{\text { Jumlah saham yang dimiliki direktur dan komisaris }}{\text { Jumlah saham yang diterbitkan }}
$$

\section{HASIL DAN PEMBAHASAN}

Pada penelitian ini telah dilakukan analisis statistik deskriptif dan pengujian asumsi klasik. Diperoleh hasil bahwa uji normalitas, uji autokorelasi, uji multikolinearitas, dan uji heteroskedastisitas telah lolos uji asumsi klasik. 


\section{Uji Hipotesis}

\section{Uji Parsial (Uji t)}

Berikut ini disajikan hasil uji parsial pada penelitian ini:

Tabel 2 Hasil Uji Parsial

\begin{tabular}{llcc}
\hline \multicolumn{1}{c}{ Model } & t & Sig. \\
\hline 1 (Constant) & 3,979 &, 000 \\
& Likuiditas & $-6,253$ &, 000 \\
& Struktur Aktiva &,- 311 &, 758 \\
Risiko Bisnis &,- 346 &, 731 \\
Growth Opportunity &, 947 &, 350 \\
Kepemilikan Manajerial &,- 067 &, 947 \\
\hline
\end{tabular}

Sumber: hasil olahan data

Berdasarkan data pada tabel 2, diperoleh hasil bahwa nilai t hitung untuk variabel likuiditas sebesar $-6,253$ dan $t$ tabel 2,030. Karena $t$ hitung lebih besar dari $t$ tabel $(-6,253>2,030)$ dan nilai signifikan $0,000<0,05$. Maka dapat disimpulkan bahwa $\mathrm{H}_{1}$ diterima, hal ini menunjukan bahwa likuiditas memiliki pengaruh dan signifikan terhadap struktur modal. Sementara itu, nilai t hitung untuk variabel struktur aktiva sebesar $-0,311$ dan $t$ tabel 2,030. Karena t hitung lebih kecil dari t tabel $(-0,311<2,030)$ dan nilai signifikan 0,758 >0,05. Maka dapat disimpulkan bahwa $\mathrm{H}_{2}$ ditolak, hal ini menunjukan bahwa tidak ada pengaruh yang signifikan antara variabel struktur aktiva dengan struktur modal. Variabel risiko bisnis memiliki nilai t hitung sebesar -0,346 dan $\mathrm{t}$ tabel 2,030. Nilai $\mathrm{t}$ hitung lebih kecil dari $\mathrm{t}$ tabel $(-0,346<2,030)$ dan nilai signifikan $0,0,731>0,05$. Maka $\mathrm{H}_{3}$ ditolak, hal ini menunjukan bahwa tidak ada pengaruh yang signifikan antara variabel risiko bisnis dengan struktur modal. Variabel growth opportunity memiliki nilai $t$ hitung 0,947 dan $t$ tabel 2,030. Nilai $t$ hitung lebih kecil dari $t$ tabel $(0,947<2,030)$ dan nilai signifikan 0,350 > 0,05. Dapat disimpulkan bahwa $\mathrm{H}_{4}$ ditolak, hal ini menunjukan bahwa tidak ada pengaruh yang signifikan antara variabel growth opportunity dengan struktur modal. Sedangkan variabel kepemilikan manajerial memiliki nilai t hitung -0,067 dan t tabel 2,030. Karena t hitung lebih kecil dari t tabel $(-0,067<$ 2,030 ) dan nilai signifikan 0,947 > 0,05. Maka dapat di simpulkan bahwa $\mathrm{H}_{4}$ ditolak, hal ini menunjukan bahwa tidak ada pengaruh yang signifikan antara variabel kepemilikan manajerial dengan struktur modal.

\section{Uji Koefisien Determinasi}

Koefisien determinasi (Adjusted $R^{2}$ ) pada intinya mengukur seberapa jauh kemampuan model dalam menerangkan variasi variabel dependen (Ghozali, 2011). Berikut ini disajikan hasil koefisien determinasi: 
Tabel 3 Koefisien Determinasi $\left(\mathbf{R}^{2}\right)$

\begin{tabular}{ccccc}
\hline Model & R & R Square & $\begin{array}{c}\text { Adjusted R } \\
\text { Square }\end{array}$ & $\begin{array}{c}\text { Std. Error of the } \\
\text { Estimate }\end{array}$ \\
\hline 1 &, $810^{\mathrm{a}}$ &, 656 &, 606 &, 19409 \\
\hline
\end{tabular}

Sumber: hasil olahan data

Berdasarkan data pada tabel 3, terlihat bahwa hasil perhitungan diperoleh nilai Koefisien Determinasi (Adjusted $R^{2}$ ) sebesar 0,606. Hal ini menunjukan bahwa variabel independen yaitu Likuiditas, Struktur Aktiva, Risiko Bisnis, Growth Oppotunity, Kepemilikan Manajerial mampu menerangkan atau menjelaskan 60,6\% terhadap Struktur Modal, sedangkan 39,4\% dijelaskan oleh faktor-faktor lain diluar penelitian ini.

\section{Pengaruh Likuiditas dalam perspektif Pecking order theory terhadap Struktur Modal}

Likuiditas berpengaruh terhadap struktur modal dikarenakan nilai likuiditas di atas rata-rata. likuiditas perusahaan berpengaruh terhadap peningkatan kinerja perusahaan tersebut atau perubahan yang terjadi baik pada jumlah aktiva lancar maupun utang lancar berpengaruh terhadap dalam meningkatnya keuntungan perusahaan. Signifikan hasil penelitian ini juga disebabkan karena sebagian besar nilai rasionya sangat baik, hal ini menyatakan perusahaan dalam keadaan baik dan menyebabkan perusahaan mempertimbangkan likuiditas untuk melihat kinerja perusahaan dalam mengurangi utang.

Perusahaan yang memiliki likuiditas yang tinggi berarti perusahaan yang memiliki internal financing yang cukup digunakan untuk membayar kewajibannya sehingga struktur modal juga berkurang. Likuiditas yang tinggi menunjukkan bahwa aset lancar yang dimilikinya lebih tinggi dibandingkan dengan kewajiban lancar (utang lancar) yang dimiliki. Sehingga perusahaan yang memiliki tingkat Likuiditas yang tinggi cenderung akan memilih pendanaan yang berasal dari dana internal perusahaan terlebih dahulu sebelum menggunakan pembiayaan yang berasal dari eksternal berupa utang. Oleh karena itu perusahaan mampu memenuhi kewajiban keuangannya tepat waktu artinya perusahaan tersebut dalam keadaan liquid dan dapat dikatakan mampu memenuhi kewajiban keuangan tepat waktu jika perusahaan tersebut memiliki alat pembayaran ataupun aktiva lancar yang lebih besar daripada utang lancar atau utang jangka pendek dan sebaliknya.

Hal ini sejalan dengan pecking order Theory, perusahaan cenderung lebih menyukai pendanaan internal dikarenakan perusahaan yang memiliki likuiditas tinggi cenderung tidak akan menggunakan pembiayaan dari utang. Hal tersebut dikarenakan perusahaan yang memiliki aktiva lancar yang besar cenderung akan mempunyai kemampuan untuk membayar utangnya lebih besar. Dengan aktiva lancar yang besar ini, perusahaan akan lebih memilih untuk mendanai kegiatan usaha dengan modal sendiri. Hal ini sesuai dengan penelitian yang dilakukan oleh Ratri and Christianti (2017), Prayogo (2016), Devi et al., (2017), dan Suweta and Dewi (2016). 


\section{Pengaruh Struktur Aktiva dalam perspektif Pecking order theory terhadap Struktur Modal}

Struktur aktiva tidak berpengaruh terhadap struktur modal dikarenakan perusahaan yang dijadikan sampel memiliki rata-rata total aset dibawah rata-rata yaitu sebesar 0,45 atau 45\%. Penelitian ini juga disebabkan karena sebagian nilai struktur aktiva kurang baik, dan sebagian lagi bernilai baik, hal ini membuat sulit untuk menyatakan perusahaan dalam keadaan baik atau buruk dan menyebabkan perusahaan tidak mempertimbangkan struktur aktiva untuk melihat struktur modal. Tidak signifikannya struktur aktiva disebabkan oleh proporsi aktiva tetap yang kecil dalam asset yang dimiliki perusahaan, sehingga ada atau tidaknya variabel ini tidak mempengaruhi keputusan menentukan struktur modal.

Selain itu tidak berpengaruhnya struktur aktiva terhadap struktur modal disini disebabkan karena aktiva tetap dalam industri barang konsumsi dapat ditutup menggunakan modal sendiri, yang membuat sebagian dana untuk aktiva tetap tersebut harus dipenuhi melalui modal sendiri dalam mendanai kebutuhan aktivanya.

Hal ini berarti perusahaan mampu menggunakan modal sendiri dalam melakukan kegiatan operasimya untuk mengembangkan usahanya akan menggunakan modal sendiri. Struktur aktiva yang rendah perusahaan akan kesulitan dalam mendapatkan pinjaman dari kreditor karena kreditor lebih tertarik pada perusahaan besar yaitu dengan struktur aktiva yang tinggi yang cenderung memilih dana dari pihak luar atau utang untuk mendanai kebutuhan modalnya. Hal ini menunjukkan bahwa semakin rendah struktur aktiva maka struktur modal rendah. Maka hal ini sejalan dengan pecking order theory menjelaskan bahwa perusahaan lebih cenderung memilih pendanaan yang berasal dari internal dari pada eksternal perusahaan.

Hasil penelitian ini didukung oleh penelitian Prayogo (2016); Novitaningtyas and Mudjiyanti (2014) yang menyatakan bahwa struktur aktiva tidak berpengaruh dan signifikan terhadap struktur modal, dimana apabila aktiva tetap perusahaan meningkat struktur modal maka rendah. Dengan demikian perusahaan akan kesulitan dalam mendapatkan pinjaman dari kreditor karena perusahaan dengan sruktur aktiva rendah, kemungkinan tidak memiliki jaminan untuk menambah utangnya melainkan menggunakan pendanaan internal.

\section{Pengaruh Risiko Bisnis dalam perspektif Pecking order theory terhadap Struktur Modal}

Pengujian $\mathrm{H}_{3}$ yaitu variabel risiko bisnis. Hasilnya menunjukan bahwa terdapat tidak ada pengaruh yang signifikan dari variabel risiko bisnis terhadap struktur modal sehingga hipotesis ditolak. Setiap perusahaan akan menghadapi risiko sebagai akibat dari dilakukannya kegiatan operasi perusahaan, baik itu berupa risiko bisnis maupun risiko utang yang harus digunakan oleh perusahaan. Risiko bisnis berhubungan dengan jenis usaha yang dipilih dari kondisi ekonomi yang dihadapi. Berdasarkan hasil analisis statistik dalam penelitian ini, risiko bisnis (RISK) tidak berpengaruh terhadap struktur modal karena nilai risiko bisnis pada perusahaan sampel banyak yang berada jauh dibawah rata-rata yaitu sebesar $10 \%$, risiko bisnis tidak berpengaruh terhadap perusahaan dikarenakan manajer 
kurang memperhatikan risiko bisnis yang dihadapi perusahaan dan tidak memperhatikan struktur modal perusahaan.

Hal ini menunjukan bahwa risiko bisnis rendah perusahaan lebih menggunakan utang yang besar yang mengakibatkan manajemen perusahaan harus mempertimbangkan risiko bisnis dalam menentukan besarnya utang karenakan risiko bisnis yang rendah biasanya lebih mudah mengembalikan pinjamannya. Jika menajemen tidak memperhatikan risiko utang perusahaan akan mengalami kebangkrutan. Dengan risiko yang kecil, perusahaan akan lebih mampu untuk mengembalikan pinjaman kepada kreditor dan lebih menggunakan utang. Kreditor juga lebih cenderung memberikan pinjaman kepada perusahaan yang memiliki risiko bisnis yang kecil. Maka hal ini betentangan dengan pecking order theory yang menyatakan lebih mengutamakan penggunaan dana internal daripada penggunaan utang maupun penerbitan saham. Hasil penelitian ini mendukung penelitian yang dilakukan oleh Lestari (2015), Seftianne and Handayani (2011), Sulistyowatie (2016).

\section{Pengaruh Growth Oppoerunity dalam perspektif Pecking Order Theory terhadap Struktur Modal}

Growth opportunity (pertumbuhan aset) tidak ada pengaruh signifikan terhadap struktur modal dikarenakan perusahaan tidak memiliki kepastian untuk tumbuh dimasa mendatang karena perusahaan sektor industri barang konsumsi memiliki pertumbuhan yang lambat dan pertumbuhan aset yang dijadikan sampel mengalami kenaikan yang kecil dari tahun sebelumnya. Pertumbuhan yang kecil menyebabkan variabel growth memiliki nilai jauh dibawah rata-rata sebesar $8 \%$ atau 0,18 angka ini sangat kecil, maka tidak adanya perubahan yang merupakan bagian dari struktur modal yang melalui utang. Growth Opportunity mengalami penurunan cenderung tidak menggunakan utang.

Hal ini menunjukan bahwa semakin rendah Growth Opportunity maka struktur modal rendah, Growth Opportunity yang rendah disebabkan perusahaan yang memiliki pertumbuhan lebih lambat sering menghadapi ketidakpastian atas tingkat pertumbuhannya dimasa mendatang, sehingga terkadang cenderung mengurangi menggunakan utang yang lebih banyak, hal ini dkarenakan perusahaan tidak memiliki kepastian tersebut menunjukan bahwa tidak adanya perubahan atas utang yang merupakan bagian dari utang.

Perusahaan bisa saja melakukan kebijakan dengan cara mengurangi kepemilikan aset yang dimiliki karena dilakukannya kebijakan penjualan untuk membiayai rencana aktivitas perusahaan. Hal ini bisa berarti pertumbuhan aset tidak digunakan oleh manajemen sebagai jaminan penambah utang untuk mengembangkan perusahaan. Peningkatan aset penjualan tersebut digunakan untuk membiayai aktivitas perusahaan. Hal ini tent lebih menguntungkan dibandingkan dengan menambah utang dengan jaminan penambah aset tersebut, karena nantinya perusahaan juga harus membayar bunga dari utang yang ditambah tersebut.

Hal ini sejalan dengan pecking order theory dinyatakan bahwa perusahaan akan cenderung mengutamakan penggunaan dana internal. Hasil penelitian ini sejalan dengan penelitian (Novitaningtyas and Mudjiyanti, 2014, dan Prayogo, 2016). 


\section{Pengaruh Kepemilikan Manajerial dalam perspektif Agency Theory terhadap Struktur Modal}

Kepemilikan manajerial tidak berpengaruh terhadap struktur modal dikarenakan dalam laporan keuangan, keadaan ini ditunjukkan dengan besarnya persentase kepemilikan saham oleh manajer. Karena hal ini merupakan informasi penting bagi pengguna laporan keuangan maka informasi ini akan diungkapkan dalam catatan atas laporan keuangan. Tetapi dalam catatan laporan keuangan walaupun manajer memiliki saham di perusahaan tersebut, proporsi kepemilikan manajerial relatif sedikit dan manajer tidak bisa menyelaraskan upaya yang dilakukan perusahaan sehingga tidak dapat mempengaruhi struktur modal untuk pengambilan keputusan.

Hal ini mungkin disebabkan rendahnya kepemilikan saham oleh komisaris dan direksi pada perusahaan sampel. Kepemilikan manajerial yang rendah dikarenakan kepemilikan saham oleh manajemen tidak cukup mampu mempengaruhi keputusan struktur modal, pihak manajemen akan lebih berhati-hati dalam menentukan sumber pendanaan. Kebijakan manajer dalam suatu perusahaan juga dibatasi oleh adanya komisaris dan kepemilikan institusional sebagai mekanisme pengelolaan perusahaan, sehingga kebijakan yang berkaitan dengan struktur modal juga tidak bisa diputuskan sendiri oleh manajer kepemilikan saham direksi dan komisaris. Hal ini menunjukkan bahwa struktur modal di suatu perusahaan juga dikendalikan oleh komisaris dan institusional, bukan diputuskan oleh manajemen atau direksi saja, tetapi komisaris dan dewan direksi pun ikut terlibat dalam pengambilan keputusan bersama dengan kepemilikan institusional.

Dalam pendekatan Keagenan (Agency Theory) menganggap struktur kepemilikan manajerial sebagai suatu instrumen atau alat yang digunakan untuk mengurangi konflik keagenan diantara beberapa klaim terhadap sebuah perusahaan. Agency theory, hubungan antara manajer dan pemegang saham digambarkan sebagai hubungan antara agent dan principal. Manajer akan memaksimalkan untuk kesejahteraan pemegang saham. Tetapi pada kenyataannya kepemilikan manajerial dalam penelitian ini rendah maka manajer tidak bisa memaksimalkan para pemegang saham yang mengakibatkan adanya konflik keagenan yang tidak bisa menyelaraskan potensi perbedaan kepentingan antara pemegang saham luar dan manajemen. Manajemen biasanya cenderung menahan sumber dana sehingga memiliki kontrol atas sumber dana tersebut, salah satu untuk tidak adanya konflik kegendaan yang terjadi utang biasanya sebagai solusi cara untuk mengurangi konflik keagendaan. Tapi hal ini bertentangan dengan kebijakan pengambilan kepurusan pihak manajer tidak akan menggunakan utang karena akan lebih berhati-hati dalam pengambilan keputusan terhadap utang yang nantinya manajer akan mengeluarkan kas nya untuk membayar utang. Penelitian ini mendukung hasil penelitian Sulistyowatie (2016), Lestari (2015), Toni (2018), Nanda and Retnani (2017), Atiqoh (2016), dan Pattinasarani (2016).

\section{SIMPULAN}

Berdasarkan hasil penelitian dapat disimpulkan bahwa likuiditas berpengaruh terhadap struktur modal. Struktur aset, risiko bisnis, growth oppotunity, kepemilikan 
manajerial tidak berpengaruh terhadap struktur modal. Penelitian selanjutnya sebaiknya menggunakan rentan waktu yang lebih panjang agar dapat memberikan variasi data yang optimal. Penelitian selanjutnya dapat memperluas objek penelitian yang digunakan. Objek penelitian dapat menggunakan seluruh perusahaan manufaktur yang terdaftar di Bursa Efek Indonesia agar hasilnya dapat digeneralisasi. Penelitian selanjutnya untuk menjadikan sampel penelitian menggunakan variabel yang lain yang dapat menjelaskan variasi struktur modal misalnya kepemilikan manajerial, variabilitas pendapatan, ukuran perusahaan.

\section{PUSTAKA ACUAN}

Agus, Harjito dan Martono. 2012. “Manajemen Keuangan.” P. 256 in Manajemen Keuangan. Yogyakarta: Ekonisia.

Devi, Ni Made Noviana Chintya, Ni Luh Gede Erni Sulindawati, and Made Arie Wahyuni. 2017. "Pengaruh Struktur Aktiva, Profitabilitas, Ukuran Perusahaan, Likuiditas, Dan Kepemilikan Manajerial Terhadap Strutur Modal (Studi Empiris Pada Perusahaan Manufaktur Yang Terdaftar Di Bursa Efek Indonesia Periode 2013-2015)." E-Journal S1 Ak Universitas Pendidikan Ganesha 7(1).

Ghozali, Imam. 2011. "Aplikasi Analisis Multivariate Dengan Program SPSS." Semarang: Badan Penerbit Universitas Diponegoro.

Kasmir. 2010. "Pengantar Manajemen Keuangan.” P. 81 in. Jakarta: Kencana Prenada Media Group.

Lestari, Sigita. 2015. "Determinan Struktur Modal Dalam Perspektif Pecking Order Theory Dan Agency Theory (Studi Empiris Pada Perusahaan Manufaktur Yang Listing Di Bei Tahun 2019-2013)." Jurnal WRA 3(1):571-90.

Mardiyanto, Handono. 2009. Intisari Manajemen Keuangan. Jakarta: Grasindo.

Munawir, S. 2001. Akuntansi Keuangan Dan Manajemen. pertama. Yogyakarta: BPFE.

Nanda, Desty Widya and Endang Dwi Retnani. 2017. "Pengaruh Profitabilitas, Kepemilikan Manajerial, Kepemilikan Institusional Dan Risiko Bisnis Terhadap Struktur Modal." Jurnal Ilmu \& Riset Akuntansi 6(3):945-62.

Novitaningtyas, T. P. and R. Mudjiyanti. 2014. "Pengaruh Karakteristik Perusahaan Terhadap Struktur Modal Pada Perusahaan Farmasi Yang Terdaftar Di Bei Periode009-2013.” Kompartemen 7(2):113-31.

Prayogo, Pungkas. 2016. "Struktur Modal Pada Perusahaan Manufaktur." Jurnal Economia 3(1):11-28.

Ratri, Anissa Mega and Ari Christianti. 2017. "Pengaruh Size, Likuiditas, Profitabilitas, Risiko Bisnis, Dan Pertumbuhan Penjualan Terhadap Struktur Modal Pada Sektor Industri Properti." Jrmb 12(1):13-24.

Santoso, Yuswanandre and Denies Priantinah. 2016. "Pengaruh Profitabilitas, Ukuran Perusahaan, Struktur Aktiva, Likuiditas, Dan Growth Opportunity Terhadap Struktur Modal Perusahaan." Jurnal Profita Edisi 4 Tahun 4(4):1-17. 
Seftianne and Ratih Handayani. 2011. "Faktor-Faktor Yang Mempengaruhi Struktur Modal Pada Perusahaan Publik Sektor Manufaktur." Jurnal Bisnis Dan Akuntansi Volume 13(No. 1):39-56.

Sulistyowatie. 2016. "Faktor-Faktor Yang Mempengaruhi Struktur Modal Pada Perusahaan Real Estate Dan Property Yang Terdaftar Di Bursa Efek Indonesia (Bei)." Journal of Chemical Information and Modeling 53(9):1689-99.

Suweta, Ni and Made Dewi. 2016. "Pengaruh Pertumbuhan Penjualan, Struktur Aktiva, Dan Pertumbuhan Aktiva Terhadap Struktur Modal." None 5(8):254359.

Toni, Antoni Anton. 2018. "Faktor-Faktor Yang Mempengaruhi Struktur Modal Perusahaan Manufaktur Di Bursa Efek Indonesia." Jurnal Benefita 1(2). 